\title{
Prevention of Sudden Death Related to Sport: The Science of Basic Life Support-From Theory to Practice
}

\author{
Rodrigo Luiz Vancini ${ }^{1}\left(\mathbb{D}\right.$, Pantelis Theodoros Nikolaidis ${ }^{2}{ }^{(0}$, Claudio Andre Barbosa de Lira ${ }^{3}{ }^{\circ}$, \\ Cássia Regina Vancini-Campanharo ${ }^{4}$, Ricardo Borges Viana ${ }^{3}{ }^{-}$, Marilia dos Santos Andrade ${ }^{5}$, \\ Thomas Rosemann ${ }^{6}$ and Beat Knechtle ${ }^{6,7, *(1)}$ \\ 1 Center for Physical Education and Sports, Federal University of Espírito Santo, Vitória 29075810, Brazil; \\ rodrigoluizvancini@gmail.com \\ 2 Exercise Physiology Laboratory, 18450 Nikaia, Greece; pademil@hotmail.com \\ 3 Department of Physical Education, Faculty of Physical Education and Dance, Federal University of Goiás, \\ Goiânia 74690-900, Brazil; andre.claudio@gmail.com (C.A.B.d.L.); vianaricardoborges@hotmail.com (R.B.V.) \\ 4 Paulista School of Nursing e São Paulo Hospital, Federal University of São Paulo, São Paulo 04024-002, \\ Brazil; vcassia@hotmail.com \\ 5 Department of Physiology, Federal University of São Paulo, São Paulo 05508-000, Brazil; \\ marilia1707@gmail.com \\ 6 Institute of Primary Care, University of Zurich, 8091 Zurich, Switzerland; thomas.rosemann@usz.ch \\ 7 Medbase St. Gallen Am Vadianplatz, 9001 St. Gallen, Switzerland \\ * Correspondence: beat.knechtle@hispeed.ch; Tel.: +41-(0)712-269-300
}

Received: 17 March 2019; Accepted: 19 April 2019; Published: 24 April 2019

\begin{abstract}
The sudden cardiac arrest (CA) and death of athletes are dramatic and emotionally impacting events for health professionals, family, and society. Although the practice of sport participation improves general health, physical fitness, and quality of life, intense physical exercise can be a trigger for CA and sudden death occasionally in the presence of known or unknown cardiac disorders (mainly hypertrophic cardiomyopathy) and risk factors (environment, health style, family, and genetic). The present review found that sudden death associated with CA was not such a common event in competitive athletes, but it might be an underestimated event in recreational athletes. Thus, considering the exponential increase in sport participation, both in a recreational or competitive way, and the rate of sudden $\mathrm{CA}$, knowledge of implementing prevention and treatment strategies is crucial. This includes preparation of health professionals and lay people in basic life support (BLS); screening and pre-participation assessment in sport programs and health education; and promotion for the recognition of CA and early completion of BLS and rapid access to automatic external defibrillator to improve the victim survival/prognosis. Thus, the purpose of this review is to provide for health professionals and lay people the most updated information, based on current guidelines, of how to proceed in an emergency situation associated with sudden CA of young adult athletes.
\end{abstract}

Keywords: sudden death; basic life support; cardiac arrest; cardiopulmonary resuscitation; physical activity; sport

\section{Introduction}

The beneficial role of sports for health has been widely acknowledged; however, sports participation is not without risks, and consequently, the development of safe conditions for athletes should be a major task for practitioners (e.g., coaches, physicians) working with them [1,2]. Sudden death associated with cardiac arrest (CA) represents one of the major challenges for emergency and 
rehabilitation medicine due to the large number of cases, and their social, economic impact, high morbidity, and mortality [1]. It has been demonstrated [1] in general population that CA Brazilian victims treated for one year in the emergency room presented a high mortality rate $(96 \%)$ and the occurrence of CA might be associated with other comorbidities such as stress, anxiety, and drugs. The annual incidence of sudden death (related to cardiac disorders) in athletes is lower than in general population. However, when it occurs, it is a cause of consternation and "shocks the general public", because it is "inadmissible" that elite athletes, who are considered "health models" for the sport spectators, die abruptly. It should be noted that heart disease is the leading cause of sudden death among athletes who are usually asymptomatic victims [2,3]. Overall, the percentage of sudden deaths occurring during or immediately after exercise is approximately $5 \%$, being higher among peoples with 35 years of age or older [2,4]. However, the frequency of sudden death among athletes varies and depends on sample size, sex, training level, type of sport, target population, geographical area, and definition of the condition [5-7].

In highly demanding sports in terms of volume and intensity in training and competitions, such as the marathon, triathlon, and ultra-marathon $[6,8,9]$, there is great heterogeneity on the etiology and frequency of sudden death $[6,8]$. It is important to note that sports with these characteristics of extreme physical effort could negatively impact the health status. Knechtle and Nikolaidis [9] reviewed the physiology and pathophysiology of ultra-marathon running and verified that this type of sport could lead to an increase in creatine-kinase concentration (this enzyme may be a marker of heart damage) and negatively impacts other cardiac biomarkers such as troponin I, electro-, and echocardiograph activities. This scenario could predispose to a sudden death. For example, Strachan et al. [10] showed that an 88-km ultra-marathon could lead to an increase in C-reactive protein, which is associated with heart attack. Moreover, a study on USA triathlon races from 1985 to 2016 reported 135 sudden deaths, resuscitated CA, and trauma-related deaths, whereas the incidence of death or CA among USAT (USA Triathlon) participants was 1.74 per 100,000 [8].

Sudden death in sports has attracted great attention by media (Table 1) showing potential risks of exercise/sport for health [11,12]. Surprisingly, health practitioners exhibited inadequate knowledge of exercise science [11], whereas athletic coaches did not sufficiently meet first-aid standards established by accredited entities [13]. This is a worrying situation since exercise professionals need to provide, in some cases, the initial medical and first aid care on the athletic field in the case of a CA [13]. Thus, the understanding of risk situations of sudden death and CA among athletes can provide information for the creation of prevention and treatment strategies and improvement of the victims' prognosis [14]. Therefore, this review aims to provide for health and exercise practitioners the more recent theoretical and practical information's of how to act in an emergency situation associated with sudden death and CA in sports. For the purpose of this study, the term 'athlete' refers to those practicing any sport or participating to exercise programs.

Table 1. News reporting sudden death associated to the sport practice $(n=16)$ with great media repercussion and cause of death (Google's database).

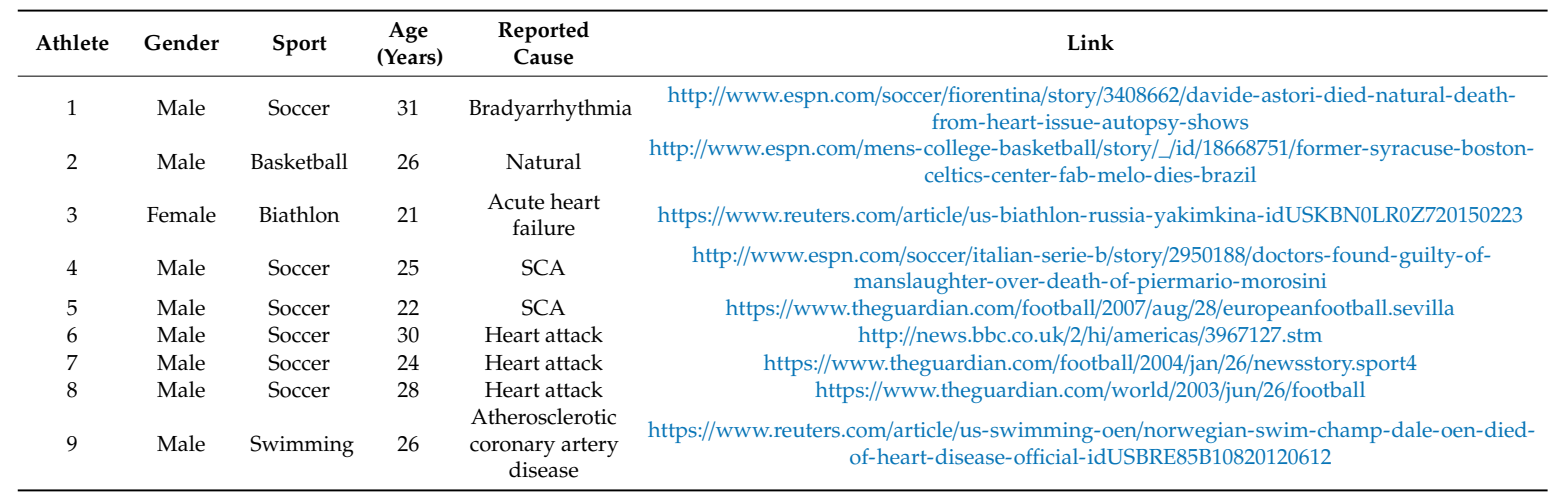


Table 1. Cont.

\begin{tabular}{|c|c|c|c|c|c|}
\hline Athlete & Gender & Sport & $\begin{array}{c}\text { Age } \\
\text { (Years) }\end{array}$ & $\begin{array}{l}\text { Reported } \\
\text { Cause }\end{array}$ & Link \\
\hline 10 & Male & Volleyball & 37 & Heart attack & $\begin{array}{c}\text { https://www.foxsports.com/olympics/story/vigor-bovolenta-dies-age-37-italian-volleyball- } \\
\text { player-olympic-silver-medalist-heart-attack-032512 }\end{array}$ \\
\hline 11 & Female & Volleyball & 26 & Thrombosis & 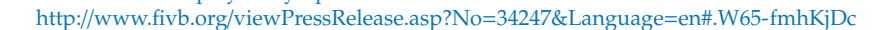 \\
\hline 12 & Male & Soccer & 26 & Heart failure & https://www.theguardian.com/football/2009/aug/09/espanyol-dani-jarque-dies \\
\hline 13 & Male & Soccer & 35 & Heart failure & https://www.theguardian.com/football/2007/dec/30/newsstory.sport2 \\
\hline 14 & Male & Soccer & 26 & Heart failure & https://www.bbc.com/sport/football/36675570 \\
\hline 15 & Male & Soccer & 25 & Heart collapse & http://edition.cnn.com/2010/SPORT/football/03/09/football.africa.deaths/index.html \\
\hline 16 & Male & Soccer & 27 & Heart failure & https://www.theguardian.com/football/2013/aug/01/christian-benitez-died-heart-failure \\
\hline
\end{tabular}

SCA: sudden cardiac arrest; the Google database was searched combining the words "sudden death" and "sport" (in the link news and all) since 2003. The access date on the abovementioned websites was 31 November 2018.

\section{Methodology}

This review was performed between 1 September 2018 and 31 November 2018 and was conducted in the following databases and according to specific purposes:

Google's database-search for emblematic cases of sudden death associated with the practice of sport and countries and localities that promote access to strategies of management and prevention of sudden CA in the context of the school. In our view, school settings are the initial place to start the propagation and consolidation of health promotion and education strategies about first aid and basic life support (BLS). The search strategies used were to cross the terms (sudden death and sport), (first aid/basic life support and school), and (teach and first aid and school).

PubMed-a broad review of the literature was carried out without the restriction of year and with the words: (i) Basic life support, (ii) first aid, (iii) automated external defibrillator (DEA, as the title word and in the abstract), (iv) sudden death, and (v) sport.

In addition, we have used other studies to provide relevant theoretical and practical information regarding to first aid and BLS.

\section{Results}

\subsection{Sudden Death and Sport: General Aspects and Presumed Causes}

Sudden death related to physical exercise and sport can be defined as an unexpected death occurring during or immediately after physical exercise (1-3 h) due to any cause, excluding violence, and may be of cardiac etiology (i.e., hypertrophic cardiomyopathy, anomalous coronary artery disease, arrhythmias, valvular diseases, myocarditis, and coronary atherosclerotic disease) and non-cardiac (i.e., use of illicit drugs, pulmonary embolism, brain diseases such as stroke and hyponatremic encephalopathy, hyperthermia, and rhabdomyolysis) [4,6,15-20].

Fortunately, sudden death in athletes is a very rare event (1:50,000-1:100,000 annually) being the result of multifactorial conditions, various disorders, and cardiovascular diseases [17]. Additionally, sudden death is related to hereditary causes, such as structural genetic cardiac conditions (which promote important morphological changes) and arrhythmias (which promote lethal electrical alterations), which are frequently found or suspected to be the cause of death in postmortem examinations in athletes $[17,21,22]$.

In these cases, for individuals with these unknown conditions, intense physical exercise may be the "trigger" for lethal cardiac arrhythmias leading to sudden death [23]. Although regular physical activity increases exercise capacity and plays a role in both primary and secondary prevention of a variety of chronic disorders [24,25], competitive and intense physical exercise is associated with a significant increase of sudden death risk in competitive athletes, especially adolescents and young adults. Several pathogenetic mechanisms have been speculated, including silent cardiovascular conditions, mostly cardiomyopathy, premature coronary artery disease, and congenital coronary anomalies [17,21-23]. Unexpected events without the presence of pathological substrates, such as commotio cordis (i.e., cardiac concussion), and abuse of unfair and dangerous doping and performance-enhancing drugs, are also potential causes [18]. However, it is well established that regular physical exercise significantly reduces 
the risk of death from all causes (including cardiac) as well as sudden death compared to a sedentary lifestyle $[12,23]$.

It should be noted that for athletes older than 35 years, coronary artery disease appears as the main cause of sudden death [2,3]. However, hypertrophic cardiomyopathy is documented as the leading cause of death in young competitive athletes (i.e., aged 35 years or less) and accounts for more than a third of the deaths $[6,17,22]$. For example, clinical diagnosis of hypertrophic cardiomyopathy is based on a hypertrophied, non-dilated left ventricle (identified by echocardiography and/or magnetic resonance imaging) in the absence of another cardiac, systemic, metabolic, or syndromic disease [17,22]. This disease is multifactorial and characterized by diverse clinical, genetic, and morphologic features, including a risk of sudden death from arrhythmia, diastolic dysfunction, or left ventricular outflow tract obstruction, which is the major determinant of progressive heart failure and sudden CA [17].

Finally, pathophysiological mechanisms of sudden death during physical exercise, and consequently CA, are most of the time, associated with the discharge of catecholamines, which interacts unfavorably with some type of pre-existing arrythmogenic substrate. In addition, intense exercise can lead to dehydration, hyperpyrexia, electrolyte imbalance, and increased platelet aggregation $[6,12,17,22]$. All these disorders and pathological substrates can lead to an abrupt loss of cardiac mechanic function and consequently to sudden CA and death [6,12]. Table 2 shows the main disturbances and disorders associated with the sudden death of athletes and general population and its respective definitions. Table 3 summarizes the prevalence of causes of sudden cardiac death in young athletes by frequency.

Table 2. Main disturbances and disorders associated with the sudden death of athletes and general population.

\begin{tabular}{|c|c|c|}
\hline Cause & Literal Definition & Reference \\
\hline Cardiomyopathies & $\begin{array}{c}\text { Defined by structural and functional abnormalities of the ventricular myocardium } \\
\text { those are unexplained by flow-limiting coronary artery disease or abnormal loading } \\
\text { conditions. }\end{array}$ & [26] \\
\hline $\begin{array}{l}\text { Hypertrophic } \\
\text { cardiomyopathy }\end{array}$ & $\begin{array}{l}\text { Defined by the presence of increased left ventricular wall thickness that is not solely } \\
\text { explained by abnormal loading conditions. }\end{array}$ & [27] \\
\hline Coronary artery anomalies & $\begin{array}{l}\text { Can be classified as anomalies with obligatory ischemia, without ischemia or with } \\
\text { exceptional ischemia. The clinical symptoms may include chest pain, dyspnea, } \\
\text { palpitations, syncope, cardiomyopathy, and arrhythmia. }\end{array}$ & [28] \\
\hline $\begin{array}{l}\text { Arrhythmia (the main is } \\
\text { ventricular fibrillation) }\end{array}$ & Electrical malfunction in the heart that causes an irregular heartbeat. & [29] \\
\hline Valvulopathies & $\begin{array}{c}\text { Changes in the heart valves, which cause stenosis or insufficiency, and may result in } \\
\text { hemodynamic problems. }\end{array}$ & [30] \\
\hline Myocarditis & $\begin{array}{l}\text { Defined as inflammation of the heart muscle that may be identified by clinical or } \\
\text { histopathologic criteria and an important cause of dilated cardiomyopathy. Viral } \\
\text { infection is an important cause. }\end{array}$ & [31] \\
\hline $\begin{array}{l}\text { Coronary atherosclerotic } \\
\text { disease }\end{array}$ & $\begin{array}{l}\text { Develops when the major blood vessels that supply heart with blood, oxygen, and } \\
\text { nutrients (coronary arteries) become damaged or diseased. Cholesterol-containing } \\
\text { deposits in arteries (plaque, accumulate at the site of injury in a process called } \\
\text { atherosclerosis) and inflammation are usually to blame for disease. }\end{array}$ & [32] \\
\hline Heart attack & $\begin{array}{l}\text { Occurs when a blocked artery prevents oxygen-rich blood from reaching a section of } \\
\text { the heart. If the blocked artery is not reopened quickly, the part of the heart normally } \\
\text { nourished by that artery begins to die. The longer a person goes without treatment, the } \\
\text { greater the damage. }\end{array}$ & [29] \\
\hline Cardiac arrest & $\begin{array}{l}\text { Occurs suddenly and often without warning. It is triggered by an electrical } \\
\text { malfunction in the heart. With its pumping action disrupted, the heart cannot pump } \\
\text { blood to the brain, lungs, and other organs. Seconds later, a person loses consciousness } \\
\text { and has no pulse. Death occurs within minutes if the victim does not receive treatment. }\end{array}$ & [29] \\
\hline Pulmonary embolism & $\begin{array}{l}\text { Characterized by occlusion of one or more pulmonary arteries. Physiological } \\
\text { disturbance may be minimal, but often cardiac output decreases as the right ventricle } \\
\text { attempts to overcome increased afterload. Additionally, ventilation-perfusion } \\
\text { mismatches can develop in affected vascular beds, reducing systemic oxygenation. }\end{array}$ & [33] \\
\hline Stroke & $\begin{array}{l}\text { Occurs when the blood supply to part of your brain is interrupted or reduced, } \\
\text { depriving brain tissue of oxygen and nutrients. Within minutes, brain cells begin to die. }\end{array}$ & [34] \\
\hline
\end{tabular}


Table 2. Cont.

\begin{tabular}{|c|c|c|}
\hline Cause & Literal Definition & Reference \\
\hline $\begin{array}{l}\text { Hyponatremic } \\
\text { encephalopathy }\end{array}$ & $\begin{array}{l}\text { Symptomatic cerebral edema due to a low osmolar state. Hyponatremia is a common } \\
\text { electrolyte disturbance occurring in a broad spectrum of patients, from asymptomatic } \\
\text { to critically ill. The disease is defined as a decrease in serum sodium concentration to a } \\
\text { level below } 136 \mathrm{mmol} \text { per liter. The brain damage from hyponatremia can be } \\
\text { associated with either hyponatremic encephalopathy or improper therapy of } \\
\text { symptomatic hyponatremia. }\end{array}$ & {$[35,36]$} \\
\hline Hyperthermia & $\begin{array}{l}\text { May be caused by excessive heat production, diminished heat dissipation, or } \\
\text { malfunction of the hypothalamic thermostat. }\end{array}$ & [37] \\
\hline Rhabdomyolysis & $\begin{array}{l}\text { Defined as injury of the skeletal muscle, which results in the release of intracellular } \\
\text { contents into the circulation. Skeletal muscle comprises } 40 \% \text { of body mass, and a large } \\
\text { insult can result in the accumulation of cellular contents in the extracellular space such } \\
\text { that elimination mechanisms are overwhelmed. The resulting effects are recognized as } \\
\text { a clinical syndrome of muscle injury that is associated with the development of } \\
\text { myoglobinuria, electrolyte abnormalities, and often acute kidney injury }\end{array}$ & [38] \\
\hline Respiratory failure & $\begin{array}{l}\text { Condition in which not enough oxygen passes from your lungs into your blood. When } \\
\text { respiratory failure causes a low level of oxygen in the blood, it is called hypoxemic } \\
\text { respiratory failure. When respiratory failure causes a high level of carbon dioxide in } \\
\text { the blood, it is called hypercapnic respiratory failure. }\end{array}$ & [39] \\
\hline Pulseless electrical activity & $\begin{array}{l}\text { Also known as electromechanical dissociation is a clinical condition characterized by } \\
\text { unresponsiveness and impalpable pulse in the presence of sufficient electrical } \\
\text { discharge. Electrical activity is a pertinent, but not sufficient, condition for contraction. } \\
\text { Also defined as organized ECG activity, excluding ventricular tachycardia and } \\
\text { fibrillation, without clinical evidence of a palpable pulse or myocardial contractions }\end{array}$ & {$[40,41]$} \\
\hline
\end{tabular}

Table 3. Summary of the prevalence of causes of sudden cardiac death in young athletes by frequency.

\begin{tabular}{cc}
\hline Coronary artery anomaly & $1: 100$ \\
Bicuspid aortic valve & $1: 100$ \\
Hypertrophic cardiomyopathy & $1: 500$ \\
Wolff-Parkinson-White & $1: 750$ \\
Short QT syndrome & $1: 2000$ \\
Arrhythmogenic right ventricular cardiomyopathy & $1: 2000$ to $1: 5000$ \\
Brugada syndrome & $1: 2000$ to $1: 5000$ \\
Long QT syndrome & $1: 2500$ \\
Dilated cardiomyopathy & $1: 2500$ \\
Marfan syndrome & $1: 5000$ \\
Catecholaminergic polymorphic ventricular tachycardia & $1: 10,000$ \\
\hline
\end{tabular}

Data from different sources [42-45].

\subsection{Cardiac Death and Sport: Is It Possible to Prevent It?}

Cardiac arrest is defined as the interruption of cardiac mechanical activity in a person expecting restoration of cardiopulmonary and cerebral function and can be considered the greatest emergency and a major public health problem $[6,46]$. During a CA event, there is circulatory inefficiency and absolute deficiency of tissue oxygenation, with the possibility of irreparable cellular damage in a short time in vital organs such as brain and heart [47]. In North America, CA is considered the leading cause of death, affecting about 350,000 individuals per year [48,49]. In Brazil, approximately 200,000 cases of CA per year are estimated to occur, half of them in an extra-hospital environment [47], which is a factor that may worsen the prognosis of victims for lack of adequate treatment, which includes speed in rescue actions and evolves knowledge in BLS [47,48].

The survival of patients after CA is around $3.4 \%$ to $22.0 \%$, with only a small proportion of the victims being discharged alive, and often with persistent neurological damage and poor quality of life [48], as we also observed in a study conducted by our research group [1]. The most common causes of CA can be divided into cardiac (i.e., acute coronary syndromes, cardiac arrhythmias, cardiac valve disease, cardiomyopathies, and congenital heart disease) and non-cardiac causes (i.e., stroke, pulmonary thromboembolism, respiratory failure, airway obstruction, and overdose of drugs and medicines) [50]. The sudden CA can occur in sports and depending on the intensity of physical exertion 
and the pre-existing disorder, affecting professional and/or recreational athletes [4,6,15-20,22]. It should be noted that the interaction between sudden death, $\mathrm{CA}$, and sport has been a focus of much interest by researchers $[6,12,23]$. Tables 4 and 5 show the main conclusions related to CA and BLS in the sport context, respectively. In summary, both tables show that cardiac structural and electrical disturbances are important causes of sudden death among athletes. In this context, population education on BLS and early BLS support and defibrillation is fundamental. These interventions could improve the prognosis of survival and neurological recovery of victims.

Table 4. Studies and their main conclusions related to cardiac arrest (CA) in the sport context.

\begin{tabular}{|c|c|c|c|c|c|c|}
\hline Author & Year & $\begin{array}{l}\text { Study } \\
\text { Type }\end{array}$ & Title & Journal & Country & Main Findings and Conclusions \\
\hline $\begin{array}{l}\text { Prech et al. } \\
\text { [51] }\end{array}$ & 2018 & $\begin{array}{l}\text { Case } \\
\text { report }\end{array}$ & $\begin{array}{l}\text { An amateur marathon } \\
\text { runner after sudden } \\
\text { cardiac arrest. Whether } \\
\text { and when can he return }\end{array}$ & $\begin{array}{l}\text { Polski Merkuriusz } \\
\text { Lekarski }\end{array}$ & Poland & $\begin{array}{c}\text { A case of an amateur runner has been presented, } \\
\text { competitor in } 50 \text { marathons, who underwent a sudden CA. } \\
\text { Reports on the possible dangers of overdosing extreme } \\
\text { endurance exercises are necessary. }\end{array}$ \\
\hline $\begin{array}{c}\text { Landry et al. } \\
\text { [52] }\end{array}$ & 2017 & Original & $\begin{array}{l}\text { Sudden cardiac arrest } \\
\text { during participation in } \\
\text { competitive sports }\end{array}$ & $\begin{array}{l}\text { The New England } \\
\text { Journal of } \\
\text { Medicine }\end{array}$ & Canada & $\begin{array}{l}\text { Incidence of sudden CA during participation in } \\
\text { competitive sports was } 0.76 \text { cases per 100,000 athlete-years } \\
\text { within a specific region of Canada, with } 43.8 \% \text { of the } \\
\text { athletes surviving until they were discharged from the } \\
\text { hospital. Two deaths were attributed to hypertrophic } \\
\text { cardiomyopathy. The occurrence of sudden CA due to } \\
\text { structural heart disease was uncommon during } \\
\text { participation in competitive sports }\end{array}$ \\
\hline $\begin{array}{l}\text { Zorzi et al. } \\
\text { [53] }\end{array}$ & 2016 & Original & $\begin{array}{l}\text { Sudden cardiac arrest in } \\
\text { Italian sports facilities in } \\
\text { 2015: epidemiological } \\
\text { implications of the } \\
\text { so-called } \\
\text { "Balduzzi decree" }\end{array}$ & $\begin{array}{l}\text { Giornale Italiano } \\
\text { di Cardiologia } \\
\quad \text { (Rome) }\end{array}$ & Italy & $\begin{array}{l}\text { After the sudden cardiac death of elite athletes in 2012, the } \\
\text { presence of an AED and professionals trained to perform } \\
\text { CPR must be available in Italian sports facilities. In 2015, it } \\
\text { was reported } 123 \text { cases of sudden CA in Italian sports } \\
\text { facilities. The majority victims were males }(93 \%) \text { and }>35 \\
\text { years old ( } 88 \% \text { ). The rate of return of spontaneous } \\
\text { circulation was } 62 \% \text { when an AED was used before } \\
\text { electromyostimulation arrival vs. } 9 \% \text { when no bystander } \\
\text { CPR or AED use by lay rescuers was mentioned. }\end{array}$ \\
\hline $\begin{array}{l}\text { Harmon et } \\
\text { al. [54] }\end{array}$ & 2016 & Original & $\begin{array}{l}\text { Incidence and etiology } \\
\text { of sudden cardiac arrest } \\
\text { and death in high } \\
\text { school athletes in the } \\
\text { United States. }\end{array}$ & $\begin{array}{l}\text { Mayo Clinic } \\
\text { Proceedings }\end{array}$ & USA & $\begin{array}{l}\text { The rate of sudden CA and death in male high school } \\
\text { athletes was 1:44,832 athletes per year, with almost half due } \\
\text { to possible or confirmed cardiomyopathy disease. }\end{array}$ \\
\hline $\begin{array}{c}\text { Solberg et al. } \\
\text { [55] }\end{array}$ & 2016 & Original & $\begin{array}{l}\text { Sudden cardiac arrest in } \\
\text { sports-need for } \\
\text { uniform registration: A } \\
\text { position paper from the } \\
\text { Sport Cardiology } \\
\text { Section of the European } \\
\text { Association for } \\
\text { cardiovascular } \\
\text { prevention and } \\
\text { rehabilitation }\end{array}$ & $\begin{array}{l}\text { European Journal } \\
\text { of Preventive } \\
\text { Cardiology }\end{array}$ & $\begin{array}{l}\text { European } \\
\text { position }\end{array}$ & $\begin{array}{l}\text { Rational decisions about cardiac pre-participation } \\
\text { screening and cardiac safety at sport facilities requires } \\
\text { increased data quality concerning incidence, etiology, and } \\
\text { management of sudden CA/sudden death in sports. }\end{array}$ \\
\hline $\begin{array}{l}\text { Cronin et al. } \\
\text { [56] }\end{array}$ & 2013 & Original & $\begin{array}{l}\text { Prepared for sudden } \\
\text { cardiac arrest? A } \\
\text { cross-sectional study of } \\
\text { automated external } \\
\text { defibrillators in } \\
\text { amateur sport }\end{array}$ & $\begin{array}{l}\text { British Journal of } \\
\text { Sports Medicine }\end{array}$ & Ireland & $\begin{array}{l}\text { A total of } 81.3 \% \text { of amateur clubs owns an AED. Many } \\
\text { clubs engage in regular maintenance and storage of AEDs. } \\
\text { However, this study identifies several areas for } \\
\text { improvement in facilitating a secure survival chain for } \\
\text { players in the event of a sudden CA. }\end{array}$ \\
\hline $\begin{array}{c}\text { Marijon et al. } \\
\text { [57] }\end{array}$ & 2013 & Original & $\begin{array}{l}\text { Characteristics and } \\
\text { outcomes of sudden } \\
\text { cardiac arrest during } \\
\text { sports in women }\end{array}$ & $\begin{array}{l}\text { Circulation: } \\
\text { Arrhythmia and } \\
\text { Electrophysiology }\end{array}$ & France & $\begin{array}{l}\text { Compared with men, the incidence of sudden cardiac death } \\
\text { in women was lower. Despite similar circumstances of } \\
\text { occurrence, survival at hospital admission }(46.5 \%) \text { was } \\
\text { significantly higher than that for men }(30.0 \%) \text {. Favorable } \\
\text { neurological outcomes were similar }(80 \%) \text {. Cause of death } \\
\text { seemed less likely to be associated with structural heart } \\
\text { disease in women compared with men ( } 58.3 \% \text { vs. } 95.8 \%) \text {. }\end{array}$ \\
\hline $\begin{array}{c}\text { Enright et al. } \\
\text { [58] }\end{array}$ & 2012 & Original & $\begin{array}{l}\text { Primary cardiac arrest } \\
\text { following sport or } \\
\text { exertion in children } \\
\text { presenting to an } \\
\text { emergency department: } \\
\text { chest compressions and } \\
\text { early defibrillation can } \\
\text { save lives, but is } \\
\text { intravenous } \\
\text { epinephrine always } \\
\text { appropriate? }\end{array}$ & $\begin{array}{c}\text { Pediatric } \\
\text { Emergency Care }\end{array}$ & Australia & $\begin{array}{l}\text { The importance of early CPR and defibrillation in collapsed } \\
\text { young athletes (with cardiac disorders that suffer CA) is } \\
\text { fundamental. These interventions could result in full } \\
\text { long-term neurological recovery. }\end{array}$ \\
\hline
\end{tabular}


Table 4. Cont.

\begin{tabular}{|c|c|c|c|c|c|c|}
\hline Author & Year & $\begin{array}{l}\text { Study } \\
\text { Type }\end{array}$ & Title & Journal & Country & Main Findings and Conclusions \\
\hline $\begin{array}{c}\text { Kramer et al. } \\
{[59]}\end{array}$ & 2010 & Review & $\begin{array}{l}\text { Review of the } \\
\text { management of sudden } \\
\text { cardiac arrest on the } \\
\text { football field }\end{array}$ & $\begin{array}{l}\text { British Journal of } \\
\text { Sports Medicine }\end{array}$ & $\begin{array}{l}\text { South } \\
\text { Africa }\end{array}$ & $\begin{array}{l}\text { Trained medical professionals must be allowed to respond, } \\
\text { ideally with a defibrillator, to a player who suddenly and } \\
\text { unexpectedly collapses on the field. Immediate } \\
\text { defibrillation of a pulseless ventricular tachycardia or } \\
\text { ventricular fibrillation has a successful cardioversion rate } \\
\text { exceeding } 90 \% \text {. Medical professionals should be well } \\
\text { trained and rehearsed in the recognition of sudden CA. } \\
\text { Prompt initiation of CPR together with early defibrillation, } \\
\text { will result in many athletes' lives being saved. }\end{array}$ \\
\hline $\begin{array}{l}\text { Cappato et } \\
\text { al. [60] }\end{array}$ & 2010 & Original & $\begin{array}{l}\text { J wave, QRS slurring, } \\
\text { and ST elevation in } \\
\text { athletes with cardiac } \\
\text { arrest in the absence of } \\
\text { heart disease: marker of } \\
\text { risk or innocent } \\
\text { bystander? }\end{array}$ & $\begin{array}{c}\text { Circulation: } \\
\text { Arrhythmia and } \\
\text { Electrophysiology }\end{array}$ & Italy & $\begin{array}{l}\text { J wave and/or QRS slurring was found more frequently } \\
\text { among athletes with CA/sudden death than in control } \\
\text { athletes. Nevertheless, the presence of this ECG pattern } \\
\text { appears not to confer a higher risk for recurrent malignant } \\
\text { ventricular arrhythmias. }\end{array}$ \\
\hline $\begin{array}{l}\text { Furlanello et } \\
\text { al. [61] }\end{array}$ & 1998 & Original & $\begin{array}{l}\text { Cardiac arrest and } \\
\text { sudden death in } \\
\text { competitive athletes } \\
\text { with ARVD }\end{array}$ & $\begin{array}{c}\text { Pacing and } \\
\text { Clinical } \\
\text { Electrophysiology }\end{array}$ & Italy & $\begin{array}{l}\text { ARVD is a predisposing factor for sport-related CA. } \\
\text { Prevalence of ARVD among athletes with CA is high, } \\
\text { confirming the observation that ARVD is one of the major } \\
\text { causes of sudden death. All CA were athletic activity } \\
\text { related, indicating the potentiality of exercise as a cause of } \\
\text { electrical destabilization in subjects with ARVD }\end{array}$ \\
\hline $\begin{array}{l}\text { Maron et al. } \\
\text { [62] }\end{array}$ & 1995 & Original & $\begin{array}{l}\text { Blunt impact to the } \\
\text { chest leading to sudden } \\
\text { death from cardiac } \\
\text { arrest during sports } \\
\text { activities }\end{array}$ & $\begin{array}{l}\text { The New England } \\
\text { Journal of } \\
\text { Medicine }\end{array}$ & USA & $\begin{array}{l}\text { Sudden death from CA in a young person may occur } \\
\text { during sports play after a blunt blow to the chest in the } \\
\text { absence of structural cardiovascular disease or traumatic } \\
\text { injury (commotio cordis). The authors identified } 25 \text { cases } \\
\text { (people of } 3-19 \text { years) from the registries. Incidents took } \\
\text { place during organized competitive sports in } 16 \text { cases and } \\
\text { in recreational settings in } 9 \text {. Twelve victims collapsed } \\
\text { virtually instantaneously on impact, whereas } 13 \text { remained } \\
\text { conscious and physically active for a brief time before CA. } \\
\text { CPR was administered within about } 3 \text { min to } 19 \text { victims, } \\
\text { but normal cardiac rhythm could be restored in only } 2 \text {. The } \\
\text { authors concluded that most sudden deaths related to } \\
\text { impact to the chest are due to ventricular dysrhythmia } \\
\text { induced by an abrupt, blunt precordial blow, presumably } \\
\text { delivered at an electrically vulnerable phase of } \\
\text { ventricular excitability. }\end{array}$ \\
\hline $\begin{array}{l}\text { Peters and } \\
\text { Reil [63] }\end{array}$ & 1995 & Original & $\begin{array}{l}\text { Risk factors of cardiac } \\
\quad \text { arrest in } \\
\text { arrhythmogenic right } \\
\text { ventricular dysplasia }\end{array}$ & $\begin{array}{l}\text { European Heart } \\
\text { Journal }\end{array}$ & Germany & $\begin{array}{c}\text { Arrhythmogenic right ventricular dysplasia is an important } \\
\text { cause of ventricular arrhythmia with a potential risk of } \\
\text { sudden cardiac death. People with structural alterations } \\
\text { and a low level of right ventricular function is at a high risk } \\
\text { of CA and strenuous exercise and sport remain most } \\
\text { important risk factors. }\end{array}$ \\
\hline $\begin{array}{l}\text { Dietlen et al. } \\
\text { [64] }\end{array}$ & 1953 & $\begin{array}{c}\text { Not } \\
\text { available }\end{array}$ & $\begin{array}{l}\text { Acute cardiac arrest in } \\
\text { sport exercise and work }\end{array}$ & $\begin{array}{l}\text { Münchner } \\
\text { Medizinische } \\
\text { Wochenschrift }\end{array}$ & Germany & Not available \\
\hline
\end{tabular}

CA: Cardiac arrest; AED: Automated external defibrillator; CPR: Cardiopulmonary resuscitation; ARVD: Arrhythmogenic right ventricular dysplasia.

Table 5. Studies and their main conclusions related to basic life support (BLS) in sports.

\begin{tabular}{|c|c|c|c|c|c|c|}
\hline Author & Year & $\begin{array}{l}\text { Study } \\
\text { Type }\end{array}$ & Title & Journal & Country & Main Findings and Conclusions \\
\hline Karam et al. [65] & 2017 & Original & $\begin{array}{c}\text { Major regional } \\
\text { differences in } \\
\text { Automated External } \\
\text { Defibrillator placement } \\
\text { and Basic Life Support } \\
\text { training in France: } \\
\text { Further needs for } \\
\text { coordinated } \\
\text { implementation }\end{array}$ & Resuscitation & France & $\begin{array}{l}\text { There is great heterogeneity in public AEDs programs } \\
\text { Population education on BLS offers an important } \\
\text { benefit, regardless of the density of AEDs implanted, } \\
\text { which should be taken into account when planning } \\
\text { public health policies to improve the survival of sudden } \\
\text { CA outside the hospital setting. }\end{array}$ \\
\hline $\begin{array}{c}\text { Gonzalez et al. } \\
\text { [66] }\end{array}$ & 2009 & $\begin{array}{l}\text { Case } \\
\text { report }\end{array}$ & $\begin{array}{l}\text { Ventricular fibrillation } \\
\text { during sport activity } \\
\text { successfully treated }\end{array}$ & $\begin{array}{l}\text { Brazilian } \\
\text { Archives of } \\
\text { Cardiology }\end{array}$ & Brazil & $\begin{array}{l}\text { Public access programs to the AED may increase } \\
\text { survival from ventricular fibrillation in the } \\
\text { out-of-hospital setting. It is necessary to stimulate the } \\
\text { training of lay people for the use of AED and BLS and } \\
\text { to disseminate these behaviors in places with great } \\
\text { circulation of people and those with high risk of sudden } \\
\text { death (sports centers and arenas). }\end{array}$ \\
\hline
\end{tabular}

AED: Automated External defibrillator; CA: Cardiac arrest; CPR: Cardiopulmonary resuscitation; BLS: Basic life support. 


\subsection{Strategies for Prevention and Treatment of Sudden Cardiac Death Related to Sport}

The implementation of strategies for the prevention and treatment of sudden CA and death, includes team and individual strategies for the management of athletes, associated with public health campaigns, such as universal (health professional and lay people) training in CPR, and the availability of automated external defibrillators (AEDs) in public settings [23]. Despite their importance in the treatment of CA, the number of AEDs in sport facilities is still inadequate to cover the needs of the increased number of athletes $[65,66]$. In this context, "The Survival Chain" advocated by AHA and BLS techniques may contribute to decrease mortality from heart disease and sudden CA, which may precipitate sudden death events that could be triggered by physical activity and sport.

However, for the promotion and education of first aid to become effective and to be transferred to diverse contexts of society and public and private spaces, including those involving the practice of physical activity and sport, it is necessary that this knowledge and information is transmitted to children and young people in elementary and secondary schools. For instance, this information could be incorporated in the curriculum of physical education course, where a couple of courses annually would cover this topic. In addition, an extra-curriculum seminar could be conducted annually for both teachers and school-children. Tables 6 and 7 show the studies and their main conclusions related to first aid and AED in the context of sport and physical activity. In addition, Table 8 shows countries that have implemented such policies in the context of the school. In summary, these three tables show that the emergency action plans and campaigns of health promotion and education among lay people and health professionals are essential to improve the outcomes of cardiac events that can lead to CA and consequently to sudden death related to physical activity and sport. However, for these health promotion and education policies and campaigns to be effective, it is necessary to follow the correct guidelines advocated by entities such as the American Heart Association (AHA), such as "The Survival Chain".

Table 6. Studies and their main conclusions and results related to first aid in the context of sport and physical activity.

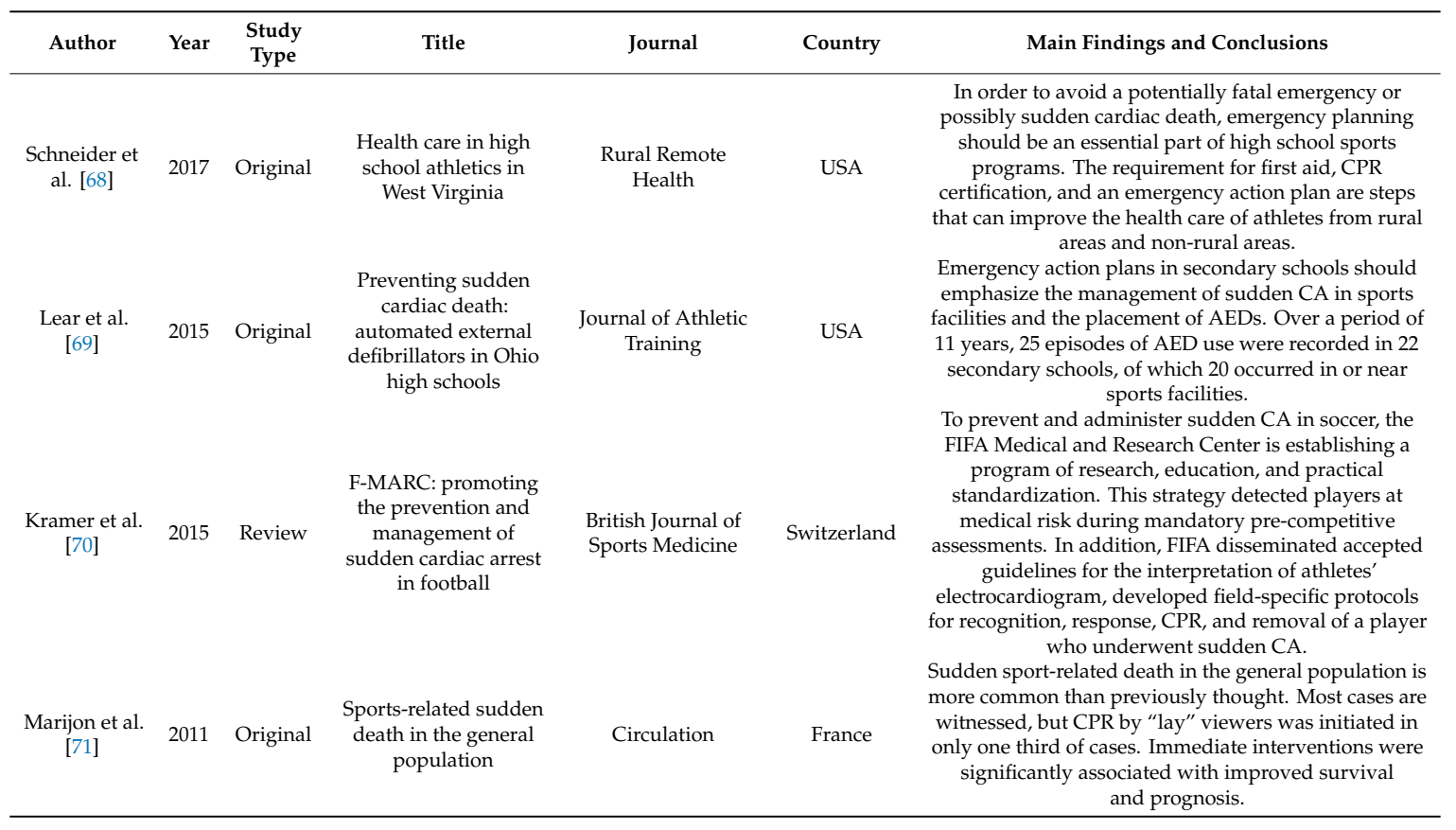


Table 6. Cont.

\begin{tabular}{|c|c|c|c|c|c|c|}
\hline Author & Year & $\begin{array}{l}\text { Study } \\
\text { Type }\end{array}$ & Title & Journal & Country & Main Findings and Conclusions \\
\hline Rich [73] & 1994 & Review & $\begin{array}{l}\text { Sudden death } \\
\text { screening }\end{array}$ & $\begin{array}{l}\text { Medical Clinics of } \\
\text { North America }\end{array}$ & USA & $\begin{array}{l}\text { Emergency plans need to be established by physicians } \\
\text { and sports coaches. The recognition of cardiac } \\
\text { symptoms associated with sudden CA is a key point. } \\
\text { Appropriate education, which includes information } \\
\text { and training in first aid, BLS and CPR, should be } \\
\text { encouraged for those working with athletes. The } \\
\text { emergency plan should include on-site treatment, the } \\
\text { way to contact Emergency medical services, and } \\
\text { transportation to a qualified health care facility. }\end{array}$ \\
\hline
\end{tabular}

CPR: Cardiopulmonary resuscitation; CA: Cardiac arrest; AED: Automated external defibrillator; BLS: Basic life support.

Table 7. Studies and their main conclusions related to automated external defibrillator in the context of sport and physical activity.

\begin{tabular}{|c|c|c|c|c|c|c|}
\hline Author & Year & Study Type & Title & Journal & Country & Main Findings and Conclusions \\
\hline $\begin{array}{c}\text { Kinoshi et al. } \\
\text { [75] }\end{array}$ & 2018 & Correspondence & $\begin{array}{l}\text { Mobile automated } \\
\text { external defibrillator } \\
\text { response system during } \\
\text { road races }\end{array}$ & $\begin{array}{l}\text { The New } \\
\text { England Journal } \\
\text { of Medicine }\end{array}$ & Japan & $\begin{array}{c}\text { Between } 2005 \text { and } 2017 \text {, of } 1,965,265 \text { runners in } \\
251 \text { road races (of } 10.0 \text { to } 42.2 \mathrm{~km} \text { ), } 30 \text { CA were } \\
\text { attended. Shocks were delivered to } 23 \text { runners } \\
\text { who had ventricular fibrillation, and another } 5 \\
\text { runners ( } 4 \text { with pulseless electrical activity and } 1 \\
\text { with ventricular fibrillation) recovered with basic } \\
\text { CPR only. The median interval between collapse } \\
\text { and the return of spontaneous circulation was } 5.5 \\
\text { min. All these runners had return of spontaneous } \\
\text { circulation in the field and had a favorable } \\
\text { neurologic outcome. }\end{array}$ \\
\hline $\begin{array}{l}\text { Fortington et } \\
\text { al. [76] }\end{array}$ & 2017 & Original & $\begin{array}{l}\text { "It doesn't make sense } \\
\text { for us not to have } \\
\text { one"-understanding } \\
\text { reasons why } \\
\text { community sports } \\
\text { organizations chose to } \\
\text { participate in a funded } \\
\text { automated external } \\
\text { defibrillator program }\end{array}$ & $\begin{array}{l}\text { Clinical Journal } \\
\text { of Sport } \\
\text { Medicine }\end{array}$ & Australia & $\begin{array}{l}\text { Implementation of AEDs in community sports } \\
\text { settings is an important component of emergency } \\
\text { medical planning. Two overarching themes } \\
\text { emerged: Awareness of the program and decision } \\
\text { to apply. }\end{array}$ \\
\hline Kramer [78] & 2013 & Editorial & $\begin{array}{c}\text { Automated external } \\
\text { defibrillator in sport: } \\
\text { absolutely always } \\
\text { available }\end{array}$ & $\begin{array}{l}\text { British Journal } \\
\text { of Sports } \\
\text { Medicine }\end{array}$ & South Africa & $\begin{array}{l}\text { Sudden CA remains the leading cause of death in } \\
\text { sports. Whenever its prevention has failed, for } \\
\text { whatever reason, its immediate medical } \\
\text { management becomes paramount if the life under } \\
\text { acute threat is to be saved. In many circumstances, } \\
\text { this can only be effectively and efficiently } \\
\text { achieved by the presence of a fully functional } \\
\text { AED which is activated while CPR is being } \\
\text { undertaken. It is no longer a question of whether } \\
\text { an AED is necessary in any mass gathering sport } \\
\text { environment but how many are necessary and } \\
\text { where they should be located }\end{array}$ \\
\hline
\end{tabular}


Table 7. Cont.

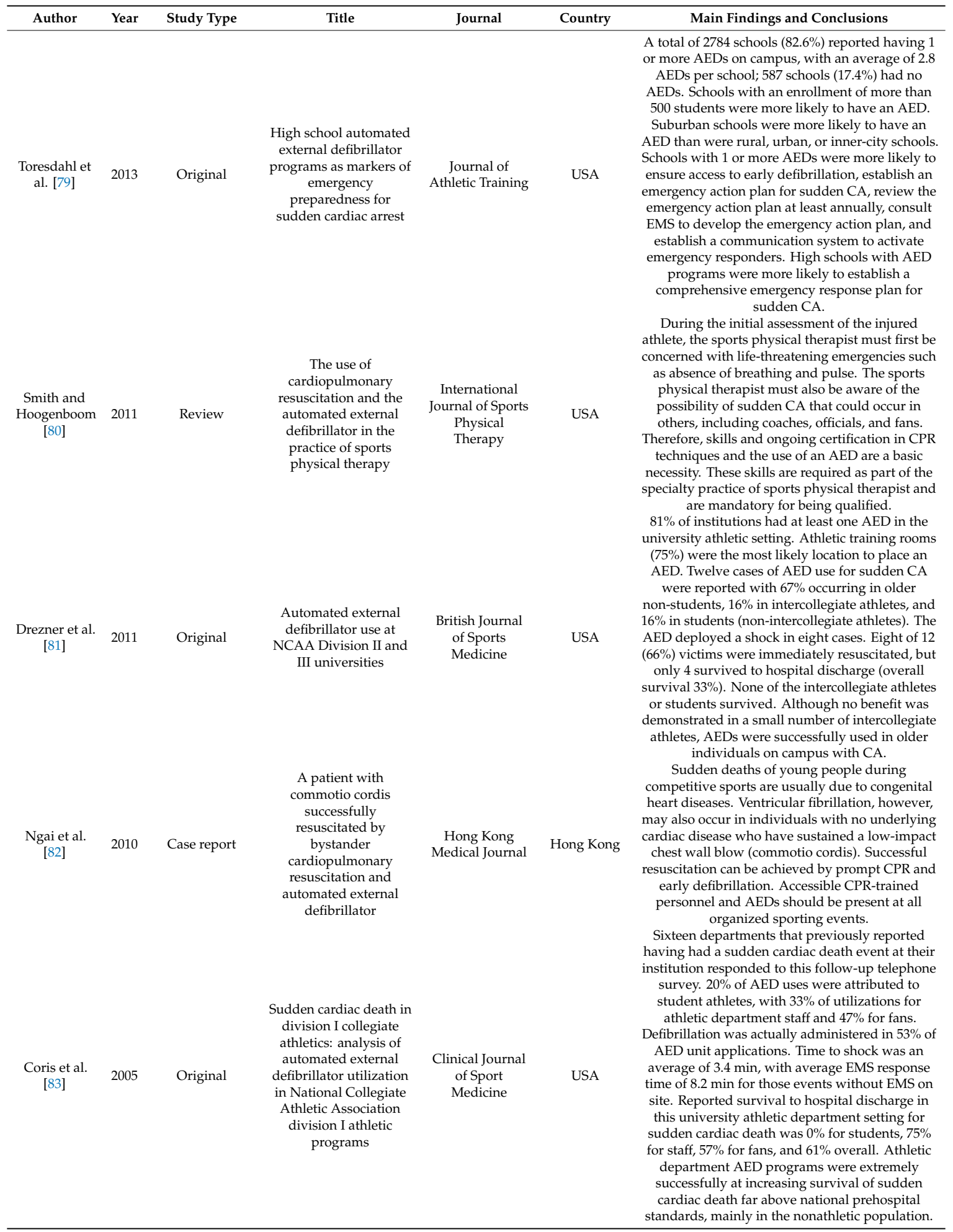

CA: Cardiac arrest; CPR: Cardiopulmonary resuscitation; AED: Automated external defibrillator; EMS: Emergency medical services. 
Table 8. Resources about promotion and education of first aid initiatives in different countries in the school context (Google's database).

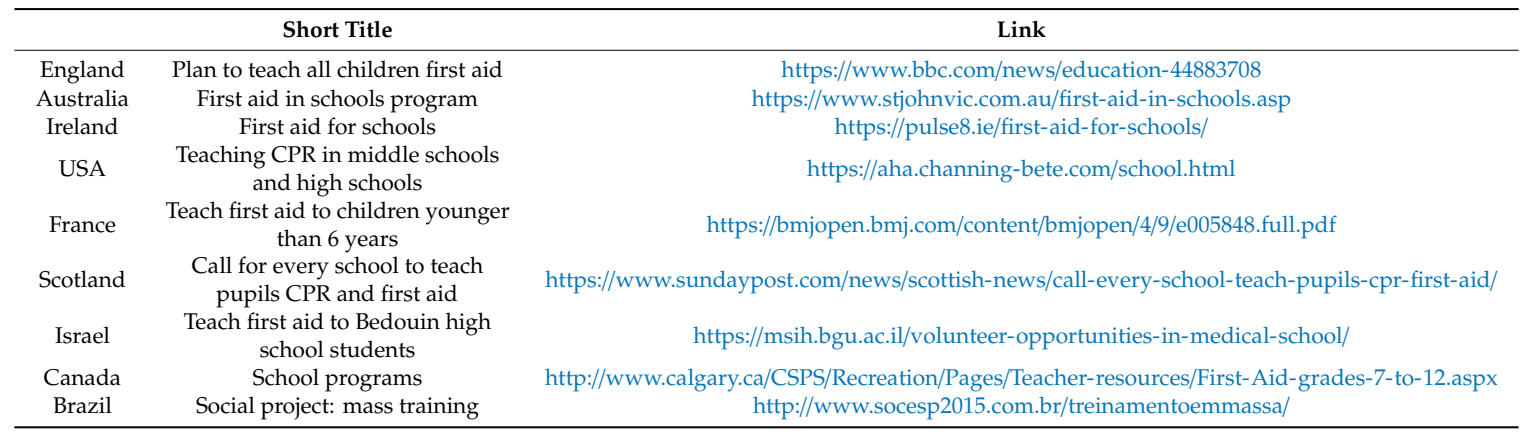

The sudden CA can occur in the context of sports (i.e., professional and/or recreational) and physical activity (i.e., occupational, leisure time, and planned/structured programs) and depend on both the intensity of physical exertion and the pre-existing disorders [4,6,15-20,22]. Thus, pre-sports assessment and monitoring to identify the presence of silent heart disease and arrhythmias may reduce the risk of sudden CA related to physical exertion [12]. Sport and physical exercise assessment and monitoring consist of screening for pre-existing cardiac diseases and should include: Anamnesis and physical examination directed to cardiovascular signs/symptoms; and family history of premature cardiac death, familial arrhythmias, and coronary artery disease [12]. In addition, the athletes' assessment should include other diagnostic exams such as the 12-lead ECG (electrocardiogram) for the investigation of arrhythmias and ischemia and, where appropriate, resting and stress ECG, pharmacological stress test, and imaging tests such as echocardiography and magnetic resonance imaging and catheterization [12].

It should be noted that in Italy, the National Health System recommends the pre-participation screening of all competitive athletes. Long-term Italian experience has provided evidence that pre-participation screening in competitive athletes with 12-lead ECG, history and physical examination is effective in identifying potentially lethal cardiovascular diseases [84]. In the USA, the American College of Cardiology/AHA recommends a pre-participation screening program limited to the use of specific questionnaires and clinical examination [85]. In addition to the pre-participation screening, preparation and training of health professionals and staff involved in the care and follow-up of athletes are essential for the recognition, care, and treatment of a sudden CA [12].

Additionally, the actions and treatment of sudden CA in adults must be based on the "Survival Chain" [86], being an algorithm and an ideal sequence of actions that must be adopted immediately after the recognition of a sudden illness, and consists of interrelated steps that must be followed so that the victims are more likely to survive/prognosis and with the lowest impacts and better possible neurological outcomes $[46,87]$. Therefore, it is necessary for health professionals, family members and laypersons to know and have training in these actions that must follow an out-of-hospital "Survival Chain" sequence presented in the Figure 1. Considering the increased risk for re-occurrence of CA, secondary prevention and cardiac rehabilitation programs are necessary for those who survived CA [88]. The main components of a subsequent cardiac rehabilitation program are presented in Figure 2. 


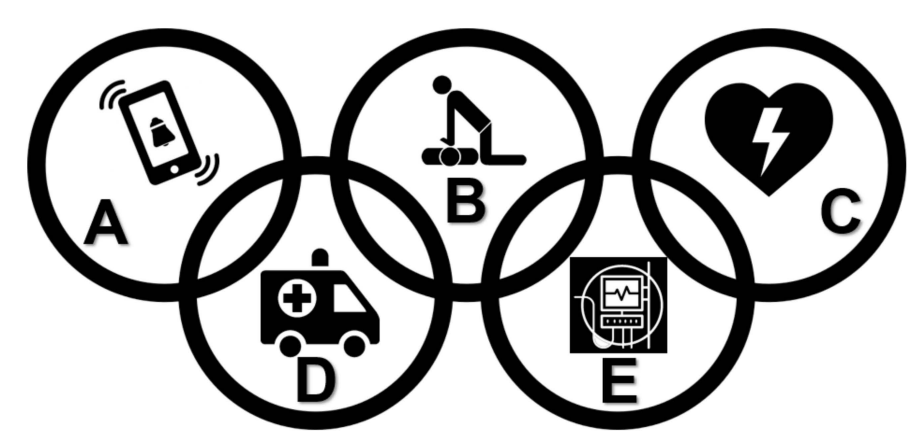

Figure 1. Out-of-hospital "Chain of Survival" of Sport (adapted from AHA [86]). (A) Recognition and activation of the emergency medical system, which varies according to country, city and locality; (B) immediate high-quality cardiopulmonary resuscitation, which includes administration/training/education in BLS; (C) rapid defibrillation-fast access to the automated external defibrillator; (D) access to advanced medical emergency services, which includes on-site care for sudden CA and transport to the in-hospital environment. (E) Advanced life support and post-cardiopulmonary resuscitation care-all of these actions occur in the hospital setting.

The BLS is a set of measures that aim to maintain blood flow to vital organs. Early recognition of sudden CA and emergency medical system (EMS) activation (currently, this is easier as we are in the "era of smartphones"), early CPR, and rapid defibrillation are key to increasing survival and improving the prognosis of victims [87]. According to the American Heart Association [29,82], the steps to perform BLS are:

1. Assess whether the location is safe in order to ensure there is no physical risk for the rescuer and the victim;

2. Evaluate if the victim is aware by touching your shoulders and asking out loud, "Are you okay?" and/or "Can you hear me?";

3. Ask for help, call the EMS, and request an AED;

4. Check at the same time whether the victim has pulse and normal breathing;

5. Observe for effective movement of the chest and palpate the carotid pulse for a maximum of $10 \mathrm{~s}$;

6. If the patient has a pulse and breathes normally, monitor the patient until the EMS arrives;

7. If the victim has a pulse but abnormal breathing, initiate rescue breaths by administering one ventilation every $6 \mathrm{~s}$. In this situation, reassess the victim every two minutes, until the EMS arrives;

8. In the absence of pulse, initiate high-quality CPR immediately, intercalating 30 external chest compressions (ECC) cycles with two ventilations, until the arrival of the EMS and AED (Figure 3).

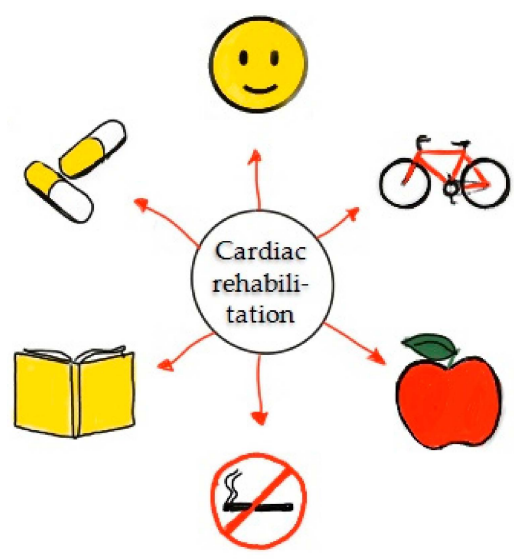

Figure 2. Components of a cardiac rehabilitation program. Such a program includes interventions on behavior, exercise, nutrition, smoking cessation, education, and medicines [88]. 


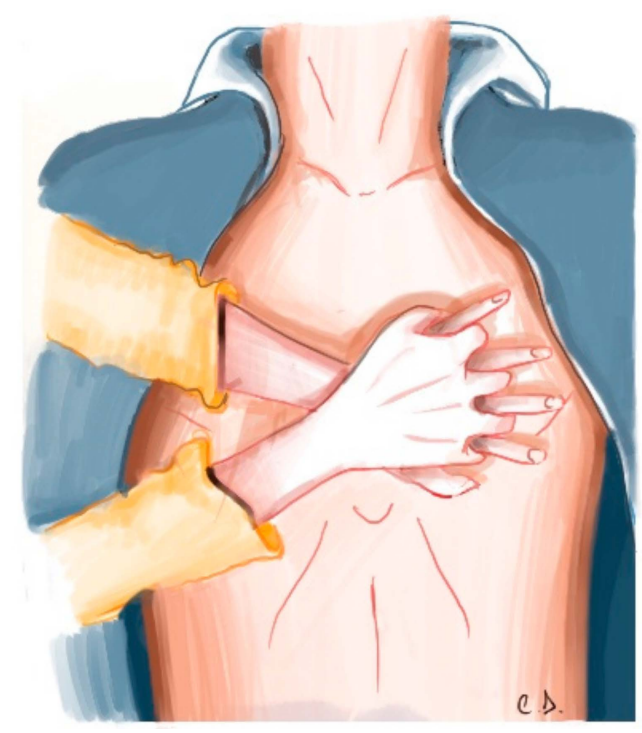

Figure 3. Location of chest compression.

With the arrival of AED, immediately stop what you are doing and according to standard procedures, position it on the victim. Do this, after opening the case and pressing the power button. The function of the AED is to proceed with the heart rhythm analysis, checking if it is a shockable rhythm or not. If it indicates a shockable rhythm, apply the shock and restart ECC immediately after. If the heart rhythm is not shockable after AED analysis, restart the ECC immediately $[29,86,87]$. According to Kleinman et al. [87] and the American Heart Association [86], the steps for performing high-quality CPR are as follows:

1. Put the victim in the supine position and on a flat and rigid surface;

2. Place the hypothenar region of the dominant hand in the lower half of the sternum of the victim and the other hand parallel to the first;

3. Keep the elbows extended, forming an angle of $90^{\circ}$ in a horizontal plane;

4. Compress the chest to the depth of 5 to $6 \mathrm{~cm}$ in a rhythm (frequency-trained in conjunction with metronome - of 100 to 120 compressions/minute, allowing the total return of the thorax at each compression;

5. After $30 \mathrm{ECC}$, perform two ventilations;

6. For ventilation to be effective, open the airways before applying them and observe the elevation of the chest at each ventilation;

7. The ventilations should be fast, lasting approximately $1 \mathrm{~s}$ and performed with the bag-valve-mask device coupled to the oxygen source (when possible);

8. Relieve the rescuer who does the ECC every two minutes, thus avoiding their fatigue and decreasing the quality of the CPR.

As a key part of BLS, defibrillation is most effective when applied early. The AED is a device capable of analyzing the heart rhythm, identifying the need for shock, and emitting an electric shock in order to return the heart to sinus rhythm [87]. However, before placing the AED, make sure that the patient is unconscious, without effective breathing, and without a pulse. Follow the instructions below [86,87], which are the universal steps for using the AED:

1. Place the adhesive pads on the patient's chest-below the right clavicle and at the apex from heart;

2. Attach the blade connector to the unit;

3. Evaluate the heart rhythm. During the analysis of the rhythm and application of the shock, make sure that you and others are away from the victim; 
4. After the shock, immediately start CPR for two minutes.

It is necessary to emphasize that some conditions can interfere in the analysis of the rhythm and the application of the shock. In case of excessive hairs on the thorax, trim them; if the victim's chest is wet, dry the site; in patients with pacemakers, apply the blades approximately 2 to $2.5 \mathrm{~cm}$ from the protuberance on the skin and when there is a medication patch on the victim's chest, remove it and position the blades $[86,87]$. BLS interventions should be maintained until the arrival of the EMS at the emergency site, so that advanced life support measures such as maintenance of an advanced airway and drug administration can be performed [87].

For children, many similarities exist compared to adults; the main differences between children and adults are [89]:

1. For children, if two rescuers are available to do CPR, the compression to breaths ratio is 15:2; if only one rescuer is available, the ratio is 30:2 for all age groups.

2. For very small children, you can use one-handed chest compressions.

3. The depth of compression may be different. For a child, compress the chest at least one-third the depth of the chest. This may be less than two inches for small children but will be approximately two inches for larger children.

4. If you are the only person at the scene and find an unresponsive child, perform CPR for two minutes BEFORE you call EMS or go and look for an AED.

5. In children, primary cardiac events are not common. Cardiac arrest is most commonly preceded by respiratory problems. Survival rates improve with early intervention for respiratory problems. Remember that prevention is the first link in the pediatric chain of survival!

6. If you witness a cardiac arrest in a child, call EMS and get an AED just as you would in the adult BLS sequence

The key question is how long CPR and BLS should be performed. Regarding CPR and BLS in athletes in the field, it must be continued until ALS (advanced life support) has arrived and the athlete will be transferred to a specialized unit where ALS will continue.

A limitation of the present review was that it focused on sports settings; thus, caution would be needed to generalize its findings to other settings, e.g., occupation. A further limitation is the fact that these studies had small sample sizes and most studies were performed with men. Therefore, the knowledge for women is small.

On the other hand, strength of this study was its novelty, since-to the best of our knowledge-it was the first one to review this topic. Considering the increased practice of exercise, reflected in the increased number of annual outdoors endurance races, such as half-marathons and full marathons [90,91], the findings would be of great practical importance for practitioners working with endurance athletes. It should be noted that this increased number of races stressed the need for availability of first aids services. In addition, it should be highlighted that the majority of these athletes were recreational athletes who started regular exercise at an adult age.

Furthermore, the risk for sudden CA as well as for any other health implication during exercise should not discourage humans from their participation in these physical activities. Instead, the risks for health during exercise should be considered in the context of weighting the risk-to-benefit ratio in these activities [92]; since exercise has a beneficial role for health, humans should be encouraged to participate in such activities despite potential risks.

\section{Conclusions}

Sudden CA due to sport participation at the presence of risk factors (in general cardiac disorders) may have known or unknown etiology; the seemingly healthy and safe practice can become the "trigger" for this tragic and dramatic event for athletes, relatives, spectators, and society in general. It is a "shocking and devastating" event, as it often involves the unexpected death of a young healthy person. 
In this context, pre-participation screening, primary prevention (cardiovascular risk assessment), and secondary strategies (training of health professionals and laypeople to perform BLS, i.e., identification of sudden CA, EMS activation, application of CPR, and early use of AED) increase chances of survival and improve the prognosis of the victims. In this way, health professionals who work directly or indirectly with athletes should be trained and seek the theoretical and technical preparation to act in emergency situations in the correct way, which may be decisive for the survival of the victims. In this sense, access to information and periodic training courses are essential and should be a mandatory part of the undergraduate curriculum and promoted, publicized, and sponsored by institutions (public and private) in the field of exercise and sport. In our view, communication of this information should be initiated in elementary and secondary schools, initially in a playful way and later in a more systematic way (e.g., courses) in accordance with the most current guidelines. Moreover, the findings of the present review highlight the need for an increased availability of AEDs in sport facilities. In summary, a combination of prevention and treatment strategies would be expected to decrease health risks-and particularly, the occurrence of sudden CA-in athletes.

Author Contributions: R.L.V. and C.A.B.d.L. conceived, designed, and performed the search strategy. R.L.V., R.B.V., and C.A.B.d.L. drafted the manuscript. C.R.V.C., M.S.A., P.T.N., B.K., T.R., R.B.V., and C.A.B.d.L. wrote and revised manuscript. All authors approved final version of manuscript.

Acknowledgments: We credit Figure 3 to Celine Dewas, specialist in medical images.

Conflicts of Interest: The authors declare no conflict of interest.

\section{References}

1. Vancini-Campanharo, C.R.; Vancini, R.L.; de Lira, C.A.B.; Andrade, M.S.; Teixeira Lopes, M.C.B.; Okuno, M.F.P.; Batista, R.E.A.; Atallah, Á.N.; de Góis, A.F.T. Characterization of cardiac arrest in the emergency department of a brazilian university reference hospital: A prospective study. Indian J. Med Res. 2016, 144, 552-559.

2. Marijon, E.; Uy-Evanado, A.; Reinier, K.; Teodorescu, C.; Narayanan, K.; Jouven, X.; Gunson, K.; Jui, J.; Chugh, S.S. Sudden cardiac arrest during sports activity in middle age. Circulation 2015, 131, 1384-1391. [CrossRef]

3. Mosterd, A. Pre-participation screening of asymptomatic athletes: "Don't do stupid stuff". Neth. Heart J. 2018, 26, 123-126. [CrossRef]

4. Sheppard, M.N. Aetiology of sudden cardiac death in sport: A histopathologist's perspective. Br. J. Sports Med. 2012, 46, i15-i21. [CrossRef] [PubMed]

5. Liberthson, R.R. Sudden death from cardiac causes in children and young adults. N. Engl. J. Med. 1996, 334, 1039-1044. [CrossRef]

6. Lippi, G.; Favaloro, E.J.; Sanchis-Gomar, F. Sudden cardiac and noncardiac death in sports: Epidemiology, causes, pathogenesis, and prevention. Semin. Thromb. Hemost. 2018, 44, 780-786.

7. Maron, B.J.; Shirani, J.; Poliac, L.C.; Mathenge, R.; Roberts, W.C.; Mueller, F.O. Sudden death in young competitive athletes: Clinical, demographic, and pathological profiles. J. Am. Med. Assoc. 1996, 276, 199-204. [CrossRef]

8. Harris, K.M.; Creswell, L.L.; Haas, T.S.; Thomas, T.; Tung, M.; Isaacson, E.; Garberich, R.F.; Maron, B.J. Death and cardiac arrest in U.S. Triathlon participants, 1985 to 2016: A case series. Ann. Intern. Med. 2017, 167, 529-536. [CrossRef]

9. Knechtle, B.; Nikolaidis, P.T. Physiology and pathophysiology in ultra-marathon running. Front. Physiol. 2018, 9, 634. [CrossRef] [PubMed]

10. Strachan, A.F.; Noakes, T.D.; Kotzenberg, G.; Nel, A.E.; de Beer, F.C. C reactive protein concentrations during long distance running. Br. Med. J. 1984, 289, 1249-1251. [CrossRef]

11. Leal, A.G.F.; Vancini, R.L.; Gentil, P.; Benedito-Silva, A.A.; da Silva, A.C.; Campos, M.H.; Andrade, M.S.; de Lira, C.A.B. Knowledge about sport and exercise science: A cross-sectional survey among health professionals in brazil. Health Educ. 2018, 118, 250-261. [CrossRef]

12. Vora, A.; Burkule, N.; Contractor, A.; Bhargava, K. Prevention of sudden cardiac death in athletes, sportspersons and marathoners in India. Indian Heart J. 2018, 70, 137-145. [CrossRef] [PubMed] 
13. Ransone, J.; Dunn-Bennett, L.R. Assessment of first-aid knowledge and decision making of high school athletic coaches. J. Athl. Train. 1999, 34, 267-271.

14. Peterson, D.F.; Siebert, D.M.; Kucera, K.L.; Thomas, L.C.; Maleszewski, J.J.; Lopez-Anderson, M.; Suchsland, M.Z.; Harmon, K.G.; Drezner, J.A. Etiology of sudden cardiac arrest and death in us competitive athletes: A 2-year prospective surveillance study. Clin. J. Sport Med. 2018. [CrossRef] [PubMed]

15. Eckart, R.E.; Scoville, S.L.; Campbell, C.L.; Shry, E.A.; Stajduhar, K.C.; Potter, R.N.; Pearse, L.A.; Virmani, R. Sudden death in young adults: A 25-year review of autopsies in military recruits. Ann. Intern. Med. 2004, 141, 829-834. [CrossRef]

16. Lobo, S.W.; Pant, S.; Kharoshah, M.A.; Senthilkumaran, S.; Riaz, N.; Menezes, R.G. Can rhabdomyolysis be a cause of sudden death in young athletes? Med. Hypotheses 2011, 77, 935. [CrossRef]

17. Maron, B.J. Clinical course and management of hypertrophic cardiomyopathy. N. Engl. J. Med. 2018, 379, 655-668. [CrossRef] [PubMed]

18. Montagnana, M.; Lippi, G.; Franchini, M.; Banfi, G.; Guidi, G.C. Sudden cardiac death in young athletes. Intern. Med. 2008, 47, 1373-1378. [CrossRef]

19. Montagnana, M.; Lippi, G.; Franchini, M.; Targher, G.; Cesare Guidi, G. Sudden cardiac death: Prevalence, pathogenesis, and prevention. Ann. Med. 2008, 40,360-375. [CrossRef]

20. Palmieri, V.; Gervasi, S.; Bianco, M.; Cogliani, R.; Poscolieri, B.; Cuccaro, F.; Marano, R.; Mazzari, M.; Basso, C.; Zeppilli, P. Anomalous origin of coronary arteries from the "wrong" sinus in athletes: Diagnosis and management strategies. Int. J. Cardiol. 2018, 252, 13-20. [CrossRef]

21. Maron, B.J. Sudden death in young athletes. N. Engl. J. Med. 2003, 349, 1064-1075. [CrossRef]

22. Maron, B.J.; Ommen, S.R.; Semsarian, C.; Spirito, P.; Olivotto, I.; Maron, M.S. Hypertrophic cardiomyopathy: Present and future, with translation into contemporary cardiovascular medicine. J. Am. Coll. Cardiol. 2014, 64, 83-99. [CrossRef] [PubMed]

23. Sweeting, J.; Semsarian, C. Sudden cardiac death in athletes. Heart Lung Circ. 2018, 27, 1072-1077. [CrossRef] [PubMed]

24. Fiuza-Luces, C.; Garatachea, N.; Berger, N.A.; Lucia, A. Exercise is the real polypill. Physiology 2013, 28, 330-358. [CrossRef]

25. Pedersen, B.K.; Saltin, B. Exercise as medicine-Evidence for prescribing exercise as therapy in 26 different chronic diseases. Scand. J. Med. Sci. Sports 2015, 25, 1-72. [CrossRef]

26. Elliott, P.; Andersson, B.; Arbustini, E.; Bilinska, Z.; Cecchi, F.; Charron, P.; Dubourg, O.; Kühl, U.; Maisch, B.; McKenna, W.J.; et al. Classification of the cardiomyopathies: A position statement from the european society of cardiology working group on myocardial and pericardial diseases. Eur. Heart J. 2008, 29, 270-276. [CrossRef]

27. Elliott, P.M.; Anastasakis, A.; Borger, M.A.; Borggrefe, M.; Cecchi, F.; Charron, P.; Hagege, A.A.; Lafont, A.; Limongelli, G.; Mahrholdt, H.; et al. 2014 esc guidelines on diagnosis and management of hypertrophic cardiomyopathy: The task force for the diagnosis and management of hypertrophic cardiomyopathy of the european society of cardiology (esc). Eur. Heart J. 2014, 35, 2733-2779.

28. Villa, A.D.; Sammut, E.; Nair, A.; Rajani, R.; Bonamini, R.; Chiribiri, A. Coronary artery anomalies overview: The normal and the abnormal. World J. Radiol. 2016, 8, 537-555. [CrossRef]

29. American Heart Association. Heart Attack or Sudden Cardiac Arrest: How Are They Different? Available online: www.heart.org/en/health-topics/heart-attack/about-heart-attacks/heart-attack-or-sudden-cardiacarrest-how-are-they-different.

30. Tarasoutchi, F.; Montera, M.W.; Grinberg, M.; Pineiro, D.J.; Sanchez, C.R.; Bacelar, A.C.; Lopes, A.S.; Fernandes, J.R.; Pires, L.J.; Moraes, R.C.; et al. Brazilian guidelines for valve disease—sbc 2011/i guideline inter-american valve disease-2011 siac. Arq. Bras. Cardiol. 2011, 97, 1-67. [CrossRef]

31. Schultz, J.C.; Hilliard, A.A.; Cooper, L.T., Jr.; Rihal, C.S. Diagnosis and treatment of viral myocarditis. Mayo Clin. Proc. 2009, 84, 1001-1009. [CrossRef]

32. Mayo Clinic Staff. Coronary Artery Disease: Symptoms and Causes. Available online: https://www. mayoclinic.org/diseases-conditions/coronary-artery-disease/symptoms-causes/syc-20350613 (accessed on 12 December 2018).

33. Hepburn-Brown, M.; Darvall, J.; Hammerschlag, G. Acute pulmonary embolism: A concise review of diagnosis and management. Intern. Med. J. 2019, 49, 15-27. [CrossRef] 
34. Mayo Clinic Staff. Stroke: Symptoms and Causes. Available online: https://www.mayoclinic.org/diseasesconditions/stroke/symptoms-causes/syc-20350113 (accessed on 12 December 2018).

35. Koźniewska, E.; Podlecka, A.; Rafałowska, J. Hyponatremic encephalopathy-Some experimental and clinical findings. Folia Neuropathol. 2003, 41, 41-45.

36. Achinger, S.G.; Ayus, J.C. Treatment of hyponatremic encephalopathy in the critically ill. Crit. Care Med. 2017, 45, 1762-1771. [CrossRef]

37. Desforges, J.F.; Simon, H.B. Hyperthermia. N. Engl. J. Med. 1993, 329, 483-487. [CrossRef]

38. Zimmerman, J.L.; Shen, M.C. Rhabdomyolysis. Chest 2013, 144, 1058-1065. [CrossRef]

39. National Heart, Lung, and Blood Institute (NHLBI). Respiratory Failure. Available online: https://www. nhlbi.nih.gov/health-topics/respiratory-failure (accessed on 12 December 2018).

40. Sadiq, U.; Grossman, S.A. Rhythm, pulseless electrical activity. In Statpearls; StatPearls Publishing LLC.: Treasure Island, FL, USA, 2019.

41. Gangadharan, S.; Nawathe, P.; Schleien, C.L. 40 cardiopulmonary resuscitation. In A Practice of Anesthesia for Infants and Children, 6th ed.; Coté, C.J., Lerman, J., Anderson, B.J., Eds.; Elsevier: Philadelphia, PA, USA, 2019; pp. 908-920.e904.

42. Ferreira, M.; Santos-Silva, P.R.; de Abreu, L.C.; Valenti, V.E.; Crispim, V.; Imaizumi, C.; Filho, C.F.; Murad, N.; Meneghini, A.; Riera, A.R.; et al. Sudden cardiac death athletes: A systematic review. Sports Med. Arthrosc. Rehabil. Ther. Technol. 2010, 2, 19. [CrossRef]

43. Asif, I.M.; Harmon, K.G. Incidence and etiology of sudden cardiac death: New updates for athletic departments. Sports Health 2017, 9, 268-279. [CrossRef] [PubMed]

44. Bohm, P.; Scharhag, J.; Meyer, T. Data from a nationwide registry on sports-related sudden cardiac deaths in Germany. Eur. J. Prev. Cardiol. 2016, 23, 649-656. [CrossRef]

45. Wasfy, M.M.; Hutter, A.M.; Weiner, R.B. Sudden cardiac death in athletes. Methodist Debakey Cardiovasc. J. 2016, 12, 76-80. [CrossRef] [PubMed]

46. Go, A.S.; Mozaffarian, D.; Roger, V.L.; Benjamin, E.J.; Berry, J.D.; Borden, W.B.; Bravata, D.M.; Dai, S.; Ford, E.S.; Fox, C.S.; et al. Heart disease and stroke statistics-2013 update: A report from the american heart association. Circulation 2013, 127, e6-e245. [CrossRef] [PubMed]

47. Gonzalez, M.M.; Timerman, S.; de Oliveira, R.G.; Polastri, T.F.; Dallan, L.A.P.; Araújo, S.; Lage, S.G.; Schmidt, A.; de Bernoche, C.S.M.; Canesin, M.F.; et al. I guideline for cardiopulmonary resuscitation and emergency cardiovascular care-Brazilian society of cardiology: Executive summary. Arq. Bras. Cardiol. 2013, 100, 105-113. [CrossRef]

48. Benjamin, E.J.; Virani, S.S.; Callaway, C.W.; Chamberlain, A.M.; Chang, A.R.; Cheng, S.; Chiuve, S.E.; Cushman, M.; Delling, F.N.; Deo, R.; et al. Heart disease and stroke statistics—2018 update: A report from the american heart association. Circulation 2018, 137, E67-E492. [CrossRef]

49. Heart Rhythm Society. Sudden Cardiac Arrest (sca). Available online: www.hrsonline.org/Patient-Resources/ Heart-Diseases-Disorders/Sudden-Cardiac-Arrest-SCA (accessed on 12 December 2018).

50. Aehlert, B. Acls, Suporte Avançado de Vida em Cardiologia: Emergências em Cardiologia, 4th ed.; Elsevier: Rio de Janeiro, Brazil, 2013.

51. Prech, M.; Bartela, E.; Szymak-Pawełczyk, B. An amateur marathon runner after sudden cardiac arrest. Whether and when can he return to sport competition? Pol. Merkur. Lek. Organ Pol. Tow. Lek. 2018, 45, 71-74.

52. Landry, C.H.; Allan, K.S.; Connelly, K.A.; Cunningham, K.; Morrison, L.J.; Dorian, P. Sudden cardiac arrest during participation in competitive sports. N. Engl. J. Med. 2017, 377, 1943-1953. [CrossRef] [PubMed]

53. Zorzi, A.; Susana, A.; Spadotto, V.; Cacciavillani, L.; Corrado, D. Sudden cardiac arrest in italian sports facilities in 2015: Possible epidemiological implications of the application of the "balduzzi decree". G. Ital. Cardiol. 2016, 17, 903-907.

54. Harmon, K.G.; Asif, I.M.; Maleszewski, J.J.; Owens, D.S.; Prutkin, J.M.; Salerno, J.C.; Zigman, M.L.; Ellenbogen, R.; Rao, A.L.; Ackerman, M.J.; et al. Incidence and etiology of sudden cardiac arrest and death in high school athletes in the united states. Mayo Clin. Proc. 2016, 91, 1493-1502. [CrossRef] [PubMed] 
55. Solberg, E.E.; Borjesson, M.; Sharma, S.; Papadakis, M.; Wilhelm, M.; Drezner, J.A.; Harmon, K.G.; Alonso, J.M.; Heidbuchel, H.; Dugmore, D.; et al. Sudden cardiac arrest in sports-Need for uniform registration: A position paper from the sport cardiology section of the european association for cardiovascular prevention and rehabilitation. Eur. J. Prev. Cardiol. 2016, 23, 657-667. [CrossRef] [PubMed]

56. Cronin, O.; Jordan, J.; Quigley, F.; Molloy, M.G. Prepared for sudden cardiac arrest? A cross-sectional study of automated external defibrillators in amateur sport. Br. J. Sports Med. 2013, 47, 1171-1174. [CrossRef] [PubMed]

57. Marijon, E.; Bougouin, W.; Celermajer, D.S.; Périer, M.C.; Dumas, F.; Benameur, N.; Karam, N.; Lamhaut, L.; Tafflet, M.; Mustafic, H.; et al. Characteristics and outcomes of sudden cardiac arrest during sports in women. Circ. Arrhythmia Electrophysiol. 2013, 6, 1185-1191. [CrossRef]

58. Enright, K.; Turner, C.; Roberts, P.; Cheng, N.; Browne, G. Primary cardiac arrest following sport or exertion in children presenting to an emergency department: Chest compressions and early defibrillation can save lives, but is intravenous epinephrine always appropriate? Pediatr. Emerg. Care 2012, 28, 336-339. [CrossRef] [PubMed]

59. Kramer, E.; Dvorak, J.; Kloeck, W. Review of the management of sudden cardiac arrest on the football field. Br. J. Sports Med. 2010, 44, 540-545. [CrossRef] [PubMed]

60. Cappato, R.; Furlanello, F.; Giovinazzo, V.; Infusino, T.; Lupo, P.; Pittalis, M.; Foresti, S.; De Ambroggi, G.; Ali, H.; Bianco, E.; et al. J wave, qrs slurring, and st elevation in athletes with cardiac arrest in the absence of heart disease marker of risk or innocent bystander? Circ. Arrhythmia Electrophysiol. 2010, 3, 305-311. [CrossRef]

61. Furlanello, F.; Bertoldi, A.; Dallago, M.; Furlanello, C.; Fernando, F.; Inama, G.; Pappone, C.; Chierchia, S. Cardiac arrest and sudden death in competitive athletes with arrhythmogenic right ventricular dysplasia. Pace Pacing Clin. Electrophysiol. 1998, 21, 331-335. [CrossRef]

62. Maron, B.J.; Poliac, L.C.; Kaplan, J.A.; Mueller, F.O. Blunt impact to the chest leading to sudden death from cardiac arrest during sports activities. N. Engl. J. Med. 1995, 333, 337-342. [CrossRef] [PubMed]

63. Peters, S.; Reil, G.H. Risk factors of cardiac arrest in arrhythmogenic right ventricular dysplasia. Eur. Heart J. 1995, 16, 77-80. [CrossRef]

64. Dietlen, H.; Mies, M.; Stormer, A. Acute cardiac arrest in sport exercise and work. Münch. Med. Wochensch. 1953, 95, 755-756.

65. Karam, N.; Narayanan, K.; Bougouin, W.; Benameur, N.; Beganton, F.; Jost, D.; Lamhaut, L.; Perier, M.C.; Cariou, A.; Celermajer, D.S.; et al. Major regional differences in automated external defibrillator placement and basic life support training in france: Further needs for coordinated implementation. Resuscitation 2017, 118, 49-54. [CrossRef]

66. Gonzalez, M.M.; Marques, F.R.B.; Vianna, C.B.; Eid, C.A.; Feitosa-Filho, G.S.; Timerman, S. Ventricular fibrillation during sport activity successfully treated. Arq. Bras. Cardiol. 2009, 93, e26-e29. [CrossRef]

67. Mills, J.D.; Moore, G.E.; Thompson, P.D. The athlete's heart. Clin. Sports Med. 1997, 16, 725-737. [CrossRef]

68. Schneider, K.; Meeteer, W.; Nolan, J.A.; Campbell, H.D. Health care in high school athletics in west virginia. Rural Remote Health 2017, 17, 1-11. [CrossRef]

69. Lear, A.; Hoang, M.H.; Zyzanski, S.J. Preventing sudden cardiac death: Automated external defibrillators in ohio high schools. J. Athl. Train. 2015, 50, 1054-1058. [CrossRef] [PubMed]

70. Kramer, E.B.; Dvorak, J.; Shmied, C.; Meyer, T. F-marc: Promoting the prevention and management of sudden cardiac arrest in football. Br. J. Sports Med. 2015, 49, 597-598. [CrossRef] [PubMed]

71. Marijon, E.; Tafflet, M.; Celermajer, D.S.; Dumas, F.; Perier, M.C.; Mustafic, H.; Toussaint, J.F.; Desnos, M.; Rieu, M.; Benameur, N.; et al. Sports-related sudden death in the general population. Circulation 2011, 124, 672-681. [CrossRef] [PubMed]

72. Brion, R. Sport-related sudden death and its prevention. Bull. L'academie Natl. Med. 2010, 194, 1237-1247.

73. Rich, B.S.E. Sudden death screening. Med. Clin. N. Am. 1994, 78, 267-288. [CrossRef]

74. Kassanoff, I.; Whaley, W.; Walter, W.H.; Burge, D.; Harrison, C.; Hurst, J.W.; Wenger, N.K. Stadium coronary care: A concept in emergency health care delivery. JAMA J. Am. Med. Assoc. 1972, 221, 397-399. [CrossRef]

75. Kinoshi, T.; Tanaka, S.; Sagisaka, R.; Hara, T.; Shirakawa, T.; Sone, E.; Takahashi, H.; Sakurai, M.; Maki, A. Mobile automated external defibrillator response system during road races. N. Engl. J. Med. 2018, 379. [CrossRef] 
76. Fortington, L.V.; Bekker, S.; Morgan, D.; Finch, C.F. "It doesn't make sense for us not to have one"-understanding reasons why community sports organizations chose to participate in a funded automated external defibrillator program. Clin. J. Sport Med. 2017. [CrossRef] [PubMed]

77. Luther, V.; Sikkel, M.B.; Wright, I.; Faulkner, M.; Qureshi, N.; Lefroy, D.C. A collapsed sportsman with a shock advised in sinus rhythm: The importance of automated external defibrillator rhythm strip retrieval prior to defibrillator implantation. Circ. Arrhythm. Electrophysiol. 2016, 9, e003914. [CrossRef] [PubMed]

78. Kramer, E.B. Automated external defibrillator in sport: Absolutely always available. Br. J. Sports Med. 2013, 47, 1138. [CrossRef]

79. Toresdahl, B.G.; Harmon, K.G.; Drezner, J.A. High school automated external defibrillator programs as markers of emergency preparedness for sudden cardiac arrest. J. Athl. Train. 2013, 48, 242-247. [CrossRef]

80. Smith, D.; Hoogenboom, B. The use of cardiopulmonary resuscitation and the automated external defibrillator in the practice of sports physical therapy. Int. J. Sports Phys. Ther. 2011, 6, 267-270.

81. Drezner, J.A.; Rogers, K.J.; Horneff, J.G. Automated external defibrillator use at ncaa division ii and iii universities. Br. J. Sports Med. 2011, 45, 1174-1178. [CrossRef] [PubMed]

82. Ngai, K.Y.; Chan, H.Y.; Ng, F. A patient with commotio cordis successfully resuscitated by bystander cardiopulmonary resuscitation and automated external defibrillator. Hong Kong Med. J. 2010, 16, 403-405.

83. Coris, E.E.; Miller, E.; Sahebzamani, F. Sudden cardiac death in division I collegiate athletics: Analysis of automated external defibrillator utilization in national collegiate athletic association division I athletic programs. Clin. J. Sport Med. 2005, 15, 87-91. [CrossRef]

84. Hevia, A.C.; Fernández, M.M.; Alacio, J.M.A.P.; Martín, E.H.; Castro, M.G.; Reguero, J.J.R. Ecg as a part of the preparticipation screening programme: An old and still present international dilemma. Br. J. Sports Med. 2011, 45, 776-779. [CrossRef] [PubMed]

85. Chatard, J.C.; Mujika, I.; Goiriena, J.J.; Carré, F. Screening young athletes for prevention of sudden cardiac death: Practical recommendations for sports physicians. Scand. J. Med. Sci. Sports 2016, 26, 362-374. [CrossRef] [PubMed]

86. American Heart Association. Highlights of the 2017 American Heart Association Focused Updates on Adult and Pediatric Basic Life Support and Cardiopulmonary Resuscitation Quality. Available online: https: //eccguidelines.heart.org/wp-content/uploads/2017/11/2017-Focused-Updates_Highlights.pdf (accessed on 12 December 2018).

87. Kleinman, M.E.; Brennan, E.E.; Goldberger, Z.D.; Swor, R.A.; Terry, M.; Bobrow, B.J.; Gazmuri, R.J.; Travers, A.H.; Rea, T. Part 5: Adult basic life support and cardiopulmonary resuscitation quality: 2015 american heart association guidelines update for cardiopulmonary resuscitation and emergency cardiovascular care. Circulation 2015, 132, S414-S435. [CrossRef]

88. Lear, S.A.; Ignaszewski, A. Cardiac rehabilitation: A comprehensive review. Trials 2001, 2, 221. [CrossRef]

89. Available online: https://nhcps.com/lesson/bls-for-children-1-8-years-old/ (accessed on 12 December 2018).

90. Vitti, A.; Nikolaidis, P.T.; Villiger, E.; Onywera, V.; Knechtle, B. The "New York City Marathon": Participation and performance trends of 1.2M runners during half-century. Res. Sports Med. 2019. [CrossRef]

91. Knechtle, B.; Di Gangi, S.; Rüst, C.A.; Rosemann, T.; Nikolaidis, P.T. Men's participation and performance in the Boston marathon from 1897 to 2017. Int. J. Sports Med. 2018, 39, 1018-1027. [CrossRef] [PubMed]

92. Fragakis, N.; Pagourelias, E.D.; Koskinas, K.C.; Vassilikos, V. Arrhythmias in athletes: Evidence-based strategies and challenges for diagnosis, management, and sports eligibility. Cardiol. Rev. 2013, 21, 229-238. [CrossRef] [PubMed]

(C) 2019 by the authors. Licensee MDPI, Basel, Switzerland. This article is an open access article distributed under the terms and conditions of the Creative Commons Attribution (CC BY) license (http://creativecommons.org/licenses/by/4.0/). 